\title{
Imagens de um lugar de memória da Educação Nova: Instituto de Educação do Rio de Janeiro nos anos de 1930
}

\author{
Sonia de Castro Lopes
}

Universidade Federal do Rio de Janeiro, Faculdade de Educação

\section{Introdução}

Tomando como referência a década de 1930 como um momento de profundas mudanças no cenário político e educacional do país, este artigo procura reconstruir algumas práticas escolares desenvolvidas no Instituto de Educação do Rio de Janeiro, à luz das inovações pedagógicas preconizadas pelos educadores ligados ao Movimento da Escola Nova.

Na medida em que se inseriam nos quadros administrativos das principais capitais do país, esses especialistas em educação dedicaram-se a estruturar um campo específico para sua atividade profissional, assim como puderam intervir na ordenação simbólica do espaço urbano de forma mais racional e científica, exercendo um controle social em nome do programa modernizador do qual se sentiam legítimos representantes.

As reformas educacionais implementadas no Distrito Federal no final dos anos de 1920 e início da década seguinte, realizadas por Fernando de Azevedo e Anísio Teixeira, revelaram a face organizacional dessa modernidade pedagógica, diante de uma população escolar heterogênea e que necessitava ser disciplinada pela educação (Nunes, 2000). Nessa cruzada pedagógica, no dizer da autora (p. 389), os professores ocupariam um espaço absolutamente central. Tratava-se, evidentemente, de um novo professor, formado no Instituto de Educação, que, no início da década de 1930, se tornou um complexo educativo composto por uma Escola de Professores, em nível superior, Escola Secundária e escolas anexas: primária e jardim-de-infância, que serviriam como campo de observação e prática aos futuros mestres.

O presente artigo utiliza-se de imagens veiculadas pelo periódico Arquivos do Instituto de Educação, publicado pela primeira vez em 1934, sob os auspícios da Secretaria de Educação do Distrito Federal. Em nossa análise, esse impresso, além de ser compreendido como objeto cultural - veículo de práticas escolares e dispositivos normatizadores de saberes destinados a um público determinado -, detém também a função de suporte de memória (Nora, 1993) - fruto da estratégia desenvolvida pelo seu produtor a fim de marcar uma nova cultura pedagógica entre professores e alunos com o objetivo de legitimar o movimento renovador do qual o Instituto de Educação seria o locus referencial.

Reforçando seu papel de veículo construtor de 
memória, a edição de 1934 oferece um conjunto de fotografias, provas "irrefutáveis" das práticas escolares que ali se desenvolviam. Entretanto, apesar de a fotografia ser a própria "memória cristalizada" (Kossoy, 2001), sua objetividade reside apenas na aparência, até porque as imagens pouco informam ou sensibilizam aos que não viveram o contexto histórico em que tais documentos se originaram.

A utilização de fotografias como objeto histórico traz para o campo da historiografia o tratamento epistemológico do olhar e da imagem, uma vez que sua articulação auxilia na análise das práticas sociais que ordenam visualmente o mundo. Assim, historiar a educação com o recurso de documentos imagéticos obriga-nos a refletir sobre a produção social do olhar, contextualizando as imagens na especificidade de práticas discursivas. Detendo uma relativa autonomia no âmbito da significação, as imagens remetem a linguagens específicas que nos auxiliam a reconstruir o contexto sociocultural, econômico e político, promovendo a totalidade que a imagem exibe de forma fragmentada (Mauad, 1996).

$\mathrm{O}$ texto divide-se em dois momentos. No primeiro, propõe-se a problematização de categorias de análise como memória, história, lugares de memória, bem como o contexto no qual foram implementadas, na cidade do Rio de Janeiro, as reformas de ensino lideradas pelos educadores ligados ao movimento da renovação educacional. Num segundo momento, busca-se superar a abordagem da imagem como mera ilustração para as análises escritas, considerando a fotografia como objeto que requer uma construção teórico-metodológica singular. Como representações da realidade, as imagens são dadas a ler, contêm uma discursividade específica, sendo apropriadas de forma diferenciada pelos consumidores e ressignificadas de acordo com o contexto histórico-social no qual circulam (Chartier, 1990).

\section{Entre memória e história}

O que seria um lugar de memória? Um espaço que abriga lembranças de algo que mereça ou precise ser preservado? Pierre Nora (1993) responde-nos que os lugares de memória estão invariavelmente vinculados a condições materiais, funcionais ou simbólicas que devem existir simultaneamente. Surgem a partir do sentimento de que não há memória espontânea, por isso é preciso criar arquivos, manter aniversários, organizar celebrações. Tais operações não são naturais, mas são necessárias, na medida em que permitem reconstruir a representação de um passado coletivo. Segundo o historiador, uma das características desses lugares seria justamente "a sua derrota em se tornar aquilo que quiseram seus fundadores, pois se estivéssemos vivendo sob seu ritmo, teriam perdido a virtude de lugares de memória" (p. 14). Observa ainda que a história, sempre crítica, na maioria das vezes repele a memória por considerá-la suspeita. Portanto, para o autor, memória e história, longe de se aproximarem, opõem-se:

A memória é vida, sempre carregada por grupos vivos, em permanente evolução, aberta à dialética lembrança/esquecimento. A história é a reconstrução sempre problemática e incompleta do que já não existe mais. A memória é um fenômeno sempre atual, um elo vivido no eterno presente; a história uma representação do passado, operação intelectual que sempre busca a análise e o discurso crítico. É justamente esse lado crítico que destrói a memória espontânea. (idem, ibidem)

Partindo da idéia de que a memória é uma reconstrução psíquica que acarreta uma representação seletiva do passado, um passado que nunca é aquele do indivíduo sozinho, mas do indivíduo inserido num contexto familiar, social ou nacional, Halbwachs (1990) afirma que a memória é sempre um processo de construção coletiva. ${ }^{1} \mathrm{O}$ sociólogo francês também distingue memória de história, afirmando que a his-

\footnotetext{
${ }^{1}$ Para Halbwachs (1990, p. 54), uma pessoa para evocar seu
} próprio passado tem freqüentemente necessidade de apelar às lembranças dos outros. Ela reporta-se a pontos de referência que existem em seu exterior e que são fixados pela sociedade. 
tória é a compilação dos fatos que ocuparam maior espaço na memória dos homens, e surge justamente pela necessidade que se tem de perpetuar fatos e lembranças normalmente esquecidos, na medida em que os grupos sociais detentores dessas lembranças também desapareceram.

Inaugurado em 1930, o edifício que abrigaria a nova Escola Normal, reformada por iniciativa de Fernando de Azevedo, diretor-geral da Instrução Pública do Distrito Federal entre 1927 e 1930, se adaptava inteiramente às novas exigências educacionais, transformando-se em uma instituição dotada de laboratórios e salas apropriadas à pesquisa, e devidamente articulada com a escola primária anexa, seu campo de experiências.

Projetado em três pavimentos, o edifício apresenta galerias de colunas em arco à volta do pátio interno, com um chafariz ao centro, para onde converge e de onde se irradia toda a vida escolar. As salas de aula, distribuídas pelos três andares do prédio, foram projetadas para abrigar com conforto os jovens alunos, tornando-se o monumento símbolo de uma nova proposta educacional para a formação do educador do Distrito Federal. Em entrevista concedida ao jornal A Noite, em 24 de maio de 1927, Fernando de Azevedo declarava:

\section{[...] O edifício será por si só uma forte, luminosa li-} ção de higiene e de civismo. As suas linhas esculturais brasileiras ensinam o gosto das nossas coisas, a inteligência e o bem-querer do país, pelo cultivo de nossas tradições mais belas e significativas. As salas amplas, harmoniosas, lavadas de luz, incutem a par com a idéia de limpeza, a de alegria tropical e sadia força de nossa natureza. (Azevedo, 1929, p. 82)

Nascia assim a nova Escola Normal do Distrito Federal, verdadeiro templo onde os futuros professores iriam absorver "a seiva do idealismo renovador, capaz de transformar a escola tradicional em uma nova escola, voltada para o trabalho e para a cooperação" (Azevedo, 1931, p. 233). Inaugurada em 1930, à mesma época da eclosão do movimento que levaria Vargas
Figura 1: Aspecto interno do prédio do Instituto de Educação do Rio de Janeiro

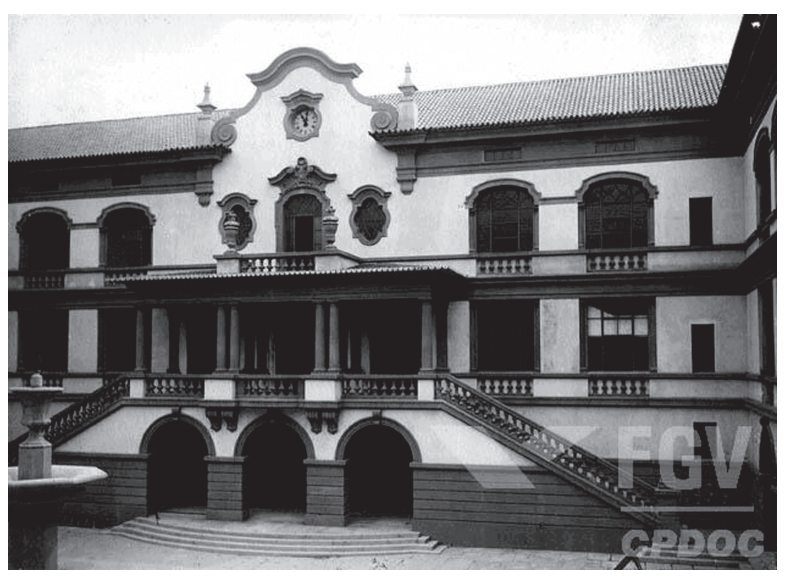

Fonte: Arquivo Lourenço Filho - CPDOC/FGV.

ao poder, a nova Escola Normal nasceria sob o signo do conflito. Refletindo a situação vigente, incorporava o estado de compromisso entre a velha e a nova ordem, reproduzindo assim a face política do momento e a face liberal do movimento da Escola Nova, que procurava adequar o sistema educacional às novas exigências da sociedade.

Pelo depoimento de ex-alunas, pode-se ter uma idéia de como os acontecimentos políticos se cruzavam com o cotidiano de alunos e professores da antiga Escola Normal. Suas lembranças sobre o episódio nos dão a dimensão de como essas representações se cristalizaram no imaginário de uma geração a respeito do turbulento período das reformas educacionais "período áureo de ensino", como fez questão de frisar uma das entrevistadas.

Eu fui uma das alunas que viveram a mudança para o prédio da Mariz e Barros. Não houve uma inauguração festiva, devido à turbulência do momento. Era outubro de 1930: a emoção, o susto, as aulas suspensas por causa da revolução. Então, um dia, a grande novidade: a ordem para começarmos a freqüentar o belíssimo prédio da Rua Mariz e Barros. [...] Cumprida a ordem, o deslumbramento: a beleza do prédio colonial na manhã de primavera, o pátio majestoso circundado de belíssimas arcadas, o chafariz, o mobiliário novo e adequado, persianas que funcionavam, o 
chão encerado... Era bem o cenário digno do período áureo do ensino que viveríamos no Distrito Federal. ${ }^{2}$

O prédio novo já estava pronto em 1930, ano em que iniciei meus estudos. A diretoria foi avisada que os soldados vinham do Rio Grande do Sul (era a revolução, não é?) e se instalariam em qualquer prédio público que estivesse vazio. E o Instituto era um prédio público que ainda não tinha sido inaugurado. O secretário Antônio Vitor passou dias e noites lá. Primeiro levaram o material dos arquivos, depois cadeiras e mesas... Todo mundo ajudava, e foi feita a mudança, em menos de uma semana. ${ }^{3}$

Entre 1931 e 1935, Anísio Teixeira ocupou o cargo de diretor de Instrução Pública do Distrito Federal em substituição a Fernando de Azevedo. Por sua iniciativa, em 1932, a recém-inaugurada Escola Normal foi transformada em instituto de educação, um centro educacional que incorporava num só estabelecimento a antiga Escola Normal e escolas anexas, jardimde-infância e escola de aplicação, com as modificações de estrutura e funcionamento fixadas pelo decreto n. 3.810, de 19 de março de 1932 (Prefeitura do Distrito Federal, 1932). Essas modificações constituíramse, principalmente, na criação de uma escola secundária e de uma Escola de Professores em nível superior, tendo como objetivo prioritário a melhoria de qualidade na formação do magistério primário, além de cursos de formação de orientadores e administradores escolares. A Escola de Professores do Instituto de Educação foi, pouco tempo depois, articulada à Universidade do Distrito Federal, também criada por Anísio em 1935, sendo responsável pela formação pedagógica dos professores secundários diplomados naquela universidade.

Com o advento do Estado Novo (1937-1945), a Universidade do Distrito Federal foi totalmente reorganizada. Vários estabelecimentos de ensino foram

\footnotetext{
${ }^{2}$ Depoimento de Baptistina Osório Berthier à autora, em 24 de junho de 2003.

${ }^{3}$ Depoimento de Marília Marques da Costa à autora, em 2 de outubro de 2001.
}

transferidos para a Universidade do Brasil, com exceção de alguns, entre eles o Instituto de Educação, que Anísio havia implantado com o objetivo de formar o magistério primário em nível superior (decreto-lei n. 1.063, art. $1^{\circ}, \S$ único) (Brasil, 1939). O curso de formação de professores secundários foi então anexado à Faculdade de Educação da nova universidade e o Instituto de Educação continuou a formar professores primários em curso secundário, na modalidade Normal.

Embora perdendo o status de Escola de Educação, o instituto manteve-se como centro de excelência de preparação para o magistério e um referencial para todo o país. O ato de sua criação - que se deveu aos renovadores enquanto ocupantes de quadros superiores na administração pública do Distrito Federal - consistiu numa tentativa de transformar os professores de todos os graus em elite competente, selecionados não pela diferenciação econômica, mas pela diferenciação das capacidades, como as únicas capazes de educar e orientar as massas populares. ${ }^{4}$

A direção do Instituto de Educação coube a Lourenço Filho, que viera de São Paulo para exercer a função de chefe de gabinete no recém-criado Ministério de Educação e Saúde. Liberado pelo ministro Francisco Campos de suas funções, Lourenço uniuse a Anísio Teixeira para alavancar o ambicioso projeto de formação de professores que teria lugar no Instituto de Educação do Distrito Federal. Em pouco menos de quinze dias organizaram aquela que seria, no dizer do professor Venâncio Filho (1945, p. 24), a “obra síntese da renovação educacional do Brasil".

\section{A escola por meio das imagens}

Os pressupostos que fundamentavam a Escola de Professores do Instituto de Educação, bem como o relato das práticas pedagógicas desenvolvidas nos

\footnotetext{
${ }^{4}$ Essa concepção autoritária de orientar as massas, típica da
} elite intelectual da época, é discutida por Chaú (1982) no artigo "Cultura do povo e autoritarismo das elites". 
diversos segmentos da instituição, encontram-se registrados no periódico Arquivos do Instituto de Educação, anuário destinado a divulgar os relatórios das atividades administrativas e relatos de práticas pedagógicas e culturais, contando com a colaboração de professores dos vários cursos mantidos pelo instituto e alguns alunos da Escola de Professores que se dispunham a relatar as experiências e pesquisas ali realizadas. À tarefa de diretor, Lourenço Filho acrescentou o seu empenho em erigir a memória da instituição e do movimento renovador, registradas nos Arquivos lugares materiais de memória, no entender de Nora (1993).

A propósito, o nome escolhido para o periódico - Arquivos - demonstra com clareza os objetivos perseguidos pelo seu criador, pois, embora pertencendo ao domínio da materialidade - um arquivo, aparentemente simples registro de dados -, esse tipo de suporte penetra também no terreno do simbólico e do funcional, uma vez que se propõe a marcar o "seu tempo" como revolucionário, adotando um tipo de linguagem e práticas específicas de um determinado grupo, autor de um projeto para a nação pela educação renovada. Segundo Nora (1993, p. 22), "a razão fundamental de ser um lugar de memória é parar o tempo, bloquear o trabalho do esquecimento, fixar um estado de coisas, imortalizar a morte, materializar o imaterial."

Percebendo a importância de seu cargo e a instabilidade do momento em que vivia, Lourenço Filho provavelmente cultivou essa memória como um dever, com um sentido de pertencimento, segredo da própria identidade individual e coletiva. Incomodava-o o fato de alguém referir-se ao instituto pelo nome da instituição que o precedera. Escola Normal era uma expressão que condenava. "Pois não se estava realizando uma verdadeira revolução? Métodos e nomes antigos indicam uma resistência ao progresso" (Brito, 1959, p. 72).

Durante a gestão de Lourenço Filho foi publicado o primeiro volume dos Arquivos, composto por três números: 1934 (v. I, n. 1), 1936 (v. I, n. 2) e 1937 (v. I, n. 3). O cuidado com essas edições revela sua estratégia para legitimar o projeto de reconstrução do Brasil pela educação, dar-lhe maior visibilidade, tomando por base a experiência desenvolvida no Instituto de Educação do Distrito Federal, escola laboratório e referencial para todo o país.

Produzido na gráfica da Secretaria de Educação do Distrito Federal, sua divulgação e circulação eram garantidas em todo o território nacional, uma vez que era enviado gratuitamente a toda rede escolar do Distrito Federal, bem como às secretarias estaduais de educação. Na verdade, a circulação desse periódico ultrapassava mesmo os limites nacionais, sendo divulgado também no exterior, como é o caso, por exemplo, da Universidade de Harvard, nos Estados Unidos, em cuja biblioteca se encontram alguns exemplares, em bom estado de conservação (Almeida, 1998, p. 224).

O volume 1, número 1, dos Arquivos de 1934, que particularmente nos interessa como fonte documental para elucidar a estrutura e o funcionamento do Instituto de Educação em seus primeiros anos de existência, contém duas formas de suporte: registros escritos e fotográficos. Ambos revelam a intenção não só de dar publicidade à obra de educação renovada que vinha sendo implementada no Instituto de Educação, mas, sobretudo, registrá-la, perpetuando-a para a posteridade. Passaremos agora a explorar as imagens presentes neste número dos Arquivos, cuidadosamente selecionadas para auxiliar no trabalho de construção de uma memória positiva não só para a instituição, mas, sobretudo, para o movimento da $e d u$ cação renovada.

Sabemos que o conhecimento do contexto é crucial para a interpretação da fotografia, imagem que seduz exatamente pela sua capacidade de preservar um fragmento do passado e transportá-lo em "aparente totalidade" para o presente. Como afirma Barthes (1984), "o que a fotografia reproduz à infinidade ocorreu apenas uma vez", logo ela "repete mecanicamente o que jamais poderia ser repetido existencialmente" (p. 13).

$\mathrm{O}$ ato de registro tem seu desenrolar em um momento histórico específico, e cada fotografia traz em 
si indicações acerca de sua elaboração mental - a tecnologia empregada - e mostra-nos um fragmento selecionado do real - o assunto registrado. Envolve, portanto, em sua produção, o sujeito, o tema e a técnica, e tem por trás de si uma história. Primeiramente, houve a intenção para que ela existisse - do próprio fotógrafo ou de um contratante, que o incumbiu da tarefa -, portanto, ela foi produzida com uma determinada finalidade. Em segundo lugar, qualquer que seja o assunto registrado na fotografia, esta também documentará a visão de mundo do fotógrafo, ainda que nem sempre se possa verificar a autoria das fotos, já que as informações a esse respeito contidas nos acervos freqüentemente são errôneas, imprecisas, ou então, inexistentes. ${ }^{5}$

A autoridade da fotografia baseia-se exatamente nessa sua presença temporal e física, pois confirma a presença e a observação do fotógrafo, bem como a "verdade" de seu relato. Mas, enquanto seu conteúdo é estático, fixado quimicamente o papel, o mesmo não ocorre com sua interpretação, que varia de acordo com a experiência cultural de seus espectadores. Poderíamos afirmar, como faz Mauad (1996), que essa interpretação remete a uma postura antropológica, cuja principal preocupação é apontar que o significado da mensagem fotográfica é convencionalizada culturalmente. Nesse sentido, a recepção da fotografia e sua compreensão "pressupõem certa aprendizagem, ligada à interação dos códigos de leitura próprios à imagem fotográfica" (p. 78).

Mas, se a imagem congela um número infinito de possibilidades - haja vista que a fotografia se constitui como uma "determinada escolha realizada num

${ }^{5}$ Kossoy (2001, p. 85) chama a atenção para as imagens fotográficas impressas em publicações mais antigas que, em geral, não mencionavam o nome do fotógrafo. A esse respeito, exemplifica com o caso de Guilherme Gaensly (1843-1928), em sua opinião o mais importante fotógrafo da paisagem de São Paulo na virada do século XIX-XX, cujas imagens foram reproduzidas em publicações brasileiras e estrangeiras sem que seu nome fosse sequer mencionado. conjunto de escolhas possíveis, guardando essa atitude uma relação estreita entre a visão de mundo daquele que aperta o botão" (Mauad, 1996, p. 79) -, são as palavras que determinam uma "certeza única", e é por isso que todas as fotografias de notícias são legendadas. O significado das fotos é, portanto, guiado ou sugerido por textos, essenciais em relação à imagem. Nesse caso, o texto orienta o leitor para os significados da imagem, levando-o a evitar alguns deles e a perceber outros, ou seja, as palavras complementam a imagem, na qual se encontram presentes, como no discurso, o remetente, a mensagem e o destinatário.

Como produto cultural, a fotografia envolve um "locus de produção e um produtor", que manipula técnicas e detém saberes específicos à sua atividade; um "destinatário ou leitor", sujeito que responde ao estímulo visual de acordo com o contexto histórico/cultural no qual está inserido; e, finalmente, um significado validado socialmente e que "resulta do trabalho de investimento de sentido" (Mauad, 1996, p. 86).

Pode-se então distinguir dois processos na análise fotográfica: o iconográfico, que se situa no nível da descrição, e não da interpretação, como nos ensina Panofsky (1979), e o iconológico, que exige uma incursão em profundidade na cena representada e só será possível se o fragmento visual for compreendido em sua interioridade. Para isso será preciso, além de conhecimentos sólidos acerca do momento histórico retratado, uma reflexão centrada no conteúdo, porém, num plano além daquele que é dado a ver pelo viés iconográfico. A interpretação fotográfica comporta, portanto, múltiplas leituras, a partir daquilo que o leitor projeta de si, em função do seu repertório cultural, da sua condição socioeconômica, de sua ideologia.

No primeiro número dos Arquivos do Instituto de Educação há uma série de 16 reproduções fotográficas concentradas na parte final da publicação, uma espécie de anexo. Entretanto, inserida no meio do periódico, servindo como abertura de um artigo que relata experiências sobre o ensino de química na escola secundária, aparece aquela que consideramos a mais expressiva de todas as imagens. Ocupando uma 
Figura 2: O presidente Vargas no Instituto de Educação

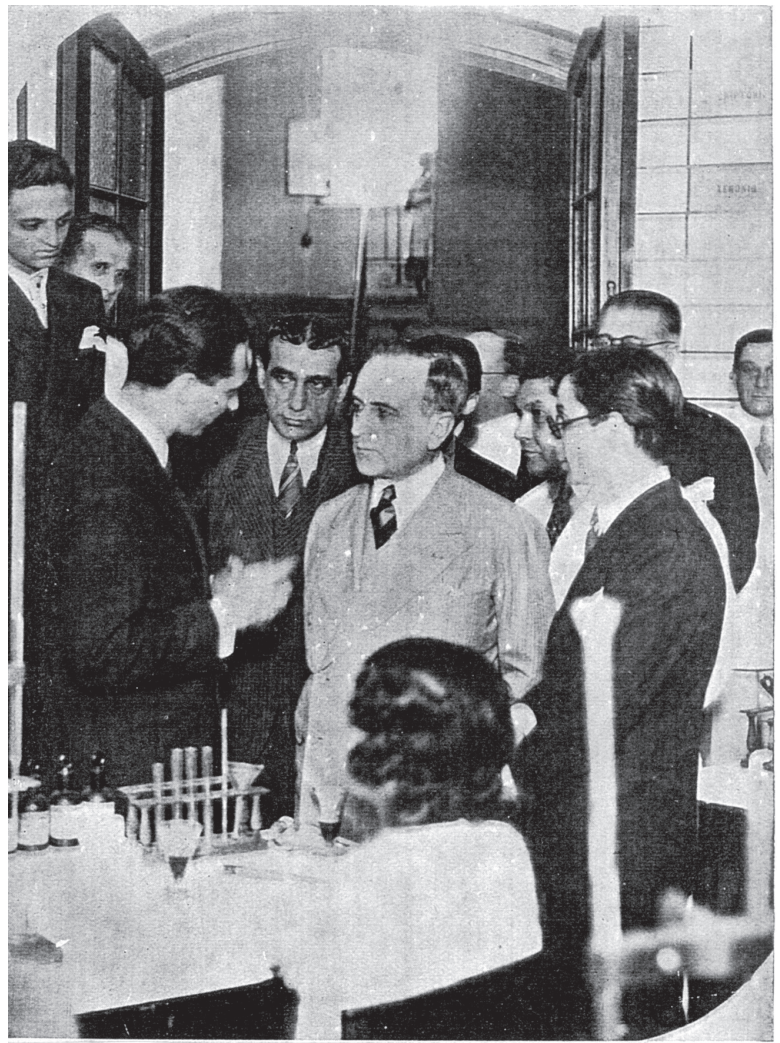

Fonte: Arquivos do Instituto de Educação, v. I, n. 1, jun. 1934, p. 49

página inteira da revista, medindo $18 \times 12 \mathrm{~cm}$, essa foto, segundo a legenda, assinala a visita dos "Exmos. Srs. Getúlio Vargas, chefe do governo da República, e Pedro Ernesto, interventor do Distrito Federal" ao Instituto de Educação.

Como o periódico não faz referência à autoria da foto, supomos tratar-se de alguma agência produtora contratada pela Secretaria de Educação do Distrito Federal, pela mensagem que esse tipo de fotografia enseja alcançar, legitimando a importância da obra educacional pelo prestígio que lhe confere a presença física das mais altas autoridades do país e da cidade o presidente Getúlio Vargas e o interventor Pedro Ernesto.

Constata-se que o autor optou por um enquadramento vertical, com a distribuição de planos de forma que reproduzisse a situação de hierarquia dos sujeitos envolvidos no registro: em primeiro plano encontra-se o presidente da República, objeto central da imagem; em seguida, um pouco mais afastado, mas ainda de frente para a câmara, vê-se o chefe do Executivo do Distrito Federal, Pedro Ernesto. Ainda em primeiro plano, de perfil, ao lado do presidente Vargas, encontra-se Anísio Teixeira, secretário de Educação do Distrito Federal, enquanto o diretor da instituição, Lourenço Filho, assume uma posição tal que somente a leitura da legenda permite percebê-lo. Entretanto, mesmo que seu nome seja omitido, revelando-se apenas a função que ocupa, seu gestual é significativo, pois encarna a autoridade que detém informações precisas e necessárias à compreensão dos fatos. Tirada em uma das salas especializadas para a prática discente, o laboratório de química da escola secundária, a foto capta, em segundo plano, a indisfarçável expressão de atenção e orgulho dos professores do instituto, e uma aluna, sentada de costas em sua mesa de pesquisa, rodeada do material de experiência necessário à aprendizagem da matéria.

As boas condições de higiene, iluminação e circulação do ambiente podem ser comprovadas pelo material utilizado no revestimento das paredes da sala - azulejos brancos, fáceis de limpar -, bem como pela altura do pé direito, que se depreende pela altura da porta de entrada. Ao fundo, no alto de uma escada, percebe-se a figura de uma mulher, cujos trajes indicam ser uma faxineira, numa atitude solícita e servil, o que reforça os valores de higiene, ordem e hierarquia que a foto pretende inculcar em seus destinatários.

Seria desnecessário evocar as razões pelas quais, em meio a tantas imagens da escola, o laboratório foi o escolhido para servir como referência às novas práticas e métodos de ensino que estavam sendo implementados pela Escola Nova naquela que se propunha a ser a instituição-modelo de formação de professores. Entretanto, contraditoriamente, ao privilegiar o evento político, abrilhantado pela presença dos chefes do Executivo, relega-se a um plano menor a importância dos novos métodos preconizados pela Escola Nova, totalmente ignorados pelos indivíduos responsáveis pela composição do argumento de "veracidade" da foto. No caso, a menina da escola se- 
cundária, foco central da nova pedagogia, é mostrada de costas, como se sua participação nesse processo fosse passiva e secundária. Assim, antes de dar visibilidade às práticas pedagógicas relatadas nos Arquivos, elegeu-se a imagem do poder como legitimador das políticas públicas em educação desenvolvidas na capital federal, fato que, se não invalida, ao menos relativiza a função de "técnicos competentes" que os educadores reformistas reivindicavam para si, e que, aliás, era corroborada pelos discursos do poder governamental.

Um conjunto de fotos menores, dispostas no anexo da revista, sugere ao leitor a possibilidade de constatar como as práticas relatadas pelos diversos autores dos artigos se processavam no interior da instituição. Essa coleção, composta por 16 reproduções fotográficas, procura contemplar todos os segmentos escolares, reforçando a idéia da unidade que se desejava imprimir à obra educacional. A série de fotografias escolares pode, assim, ser desmembrada em quatro subséries: a) fotografias sobre a Escola Primária; b) fotografias sobre a Escola Secundária; c) fotografias sobre a Escola de Professores; d) fotografias sobre a edificação escolar.

Reproduziremos a seguir apenas um exemplar de cada subsérie, levando-se em conta os limites impostos por este trabalho e o mau estado de conservação do periódico em que as fotos estão inseridas. A Figura 3 reproduz uma imagem fotográfica enquadrada horizontalmente, nas dimensões 10 x $16 \mathrm{~cm}$, na qual alunos da Escola Primária, sentados em grupos organizados por eles próprios, como informa a legenda, trabalham na realização de projetos. A sala, situada no andar térreo do prédio, é ampla, bem iluminada, com pé-direito alto, imensas janelas envidraçadas e paredes cobertas por murais e cartazes. O fotógrafo capta a atitude interessada e ao mesmo tempo organizada dos alunos, que demonstram autonomia e disciplina. Alguns se dedicam à leitura ou escrita, numa atitude mais individualista, mas a disposição das carteiras, favorecendo o agrupamento de alguns deles, sugere uma ação cooperativa e solidária. $\mathrm{O}$ objeto central da foto são as crianças - centro da aprendiza-
Figura 3: Aspecto de uma sala de aula da Escola Primária do Instituto de Educação

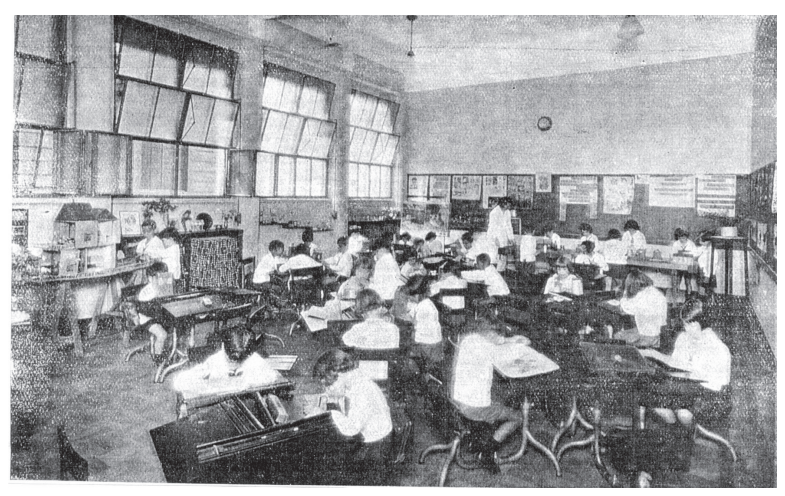

Fonte: Arquivos do Instituto de Educação, v.1, n. 1, jun. 1934. (encarte).

gem -, reservando-se para a professora um plano ao fundo da sala. A visão de alguns alunos de pé sugere um comportamento ativo e a ausência de uma disciplina rígida.

A disposição do espaço individual dos alunos no interior da sala revela uma das intervenções no espaço escolar preconizadas pelo movimento renovador, especialmente na gestão de Anísio Teixeira à frente do Departamento de Educação do Distrito Federal. Tal modelo recusava a seqüência linear das carteiras enfileiradas, com todos os alunos voltados para o espaço onde se colocava a professora, denotando uma hierarquia a ser respeitada. Na foto em tela, o agrupamento das carteiras permitia o trabalho em grupo, os alunos posicionados de frente uns para os outros. Tratava-se de negar o método simultâneo de organização da classe, conferindo centralidade às crianças em detrimento da figura da professora na relação ensinoaprendizagem. Construía-se assim o cenário ideal para o desenvolvimento das práticas pedagógicas preconizadas pela Escola Nova (Vidal \& Paulilo, 2003).

Pelo peso das fotos representativas de salas-ambientes da Escola Secundária depreende-se a relevância desse curso no conjunto do projeto. A seleção de candidatos à Escola de Professores processava-se num primeiro momento, pelo concurso de admissão a essa escola, que também servia como preparatório aos alunos que quisessem prosseguir os estudos em ouros cursos superiores. 
O processo de seleção iniciava-se por um rigoroso exame de saúde, e somente os aprovados eram submetidos aos testes de inteligência com objetivo de aproveitar os de maior capacidade intelectual. A partir dessa primeira seleção, processavam-se as provas escritas eliminatórias de aritmética e português e os exames orais classificatórios de aritmética, português, ciências, geografia e história, sendo considerados habilitados aqueles que, no conjunto, conseguissem o mínimo de 50 pontos. Uma última prova - de desenho - servia para classificar os candidatos, que muitas vezes nem chegavam a preencher as vagas oferecidas. $^{6}$

A seleção rigorosa a que essas crianças eram submetidas revela, em larga medida, o grau de exclusão operado pela instituição, bem como uma contradição com os princípios da educação renovada, pelo tipo de avaliação que se processava a partir de um conhecimento verbalístico, sofregamente acumulado nos cursinhos e em escolas preparatórias que só beneficiavam as candidatas de melhor condição socioeconômica, embora houvesse algumas exceções, como, por exemplo, certas alunas muito aplicadas que obtinham aulas gratuitas nas tais escolas, ou um reforço, graças à generosidade de suas professoras da rede pública. Sem disfarçar o orgulho, algumas ex-alunas revelam a experiência traumática por que passaram submetidas a todos esses testes, sobretudo as provas orais, realizadas no auditório, diante de uma banca de professores e das demais candidatas que, como seus familiares, tinham acesso àquela sessão de "torturas". Quase todas recordam, com riqueza de detalhes, o seu ingresso no instituto, lembrando, inclusive, o nome de seus argüidores e os pontos sorteados:

Entrei no Instituto em 1932, no ano em que houve aquela reforma toda. Quem me aplicou a prova de portu-

${ }^{6}$ Em 1933, nas provas de admissão ao instituto, apresentaram-se 949 concorrentes, e em 1934, 861 concorrentes, dos quais apenas 172 foram aceitos para as 200 vagas oferecidas. Cf. Arqui$\operatorname{vos} \ldots(1934$, p. 32). guês foi o professor Clóvis Monteiro. [...] O professor de matemática, o nome eu não lembro, mandou que eu fosse ao quadro resolver uma porção de contas, assim na frente de todo mundo, no auditório. [...] Na prova de geografia, o ponto sorteado foi a Bahia, perguntavam os rios, montanhas, tudo que dizia respeito ao Estado, e eu me saí bem. O meu medo era desenho, mas depois, lá no instituto, foi um dos melhores resultados que eu tive... ${ }^{7}$

Nem todas as meninas, então com 11 ou 12 anos, revelavam uma vocação inata para o magistério, mas as aptidões iam sendo buriladas ao longo da Escola Secundária, que selecionava os "mais capazes". A falta de aptidão para o desenho livre, por exemplo, mereceu um artigo do professor Nereo Sampaio, da Escola Secundária, no qual concluía que "o Desenho é uma disciplina que se estuda como qualquer outra, e na qual as vocações se manifestam do mesmo modo que nas demais, isto é, sem que seja necessário possuir vocação para aprendê-la" (Sampaio, 1934, p. 48).

Assim, graças às técnicas introduzidas nas diversas disciplinas pelos professores da escola secundária, iam-se desenvolvendo dons, habilidades e apti-

Figura 4: Sala-ambiente de Desenho

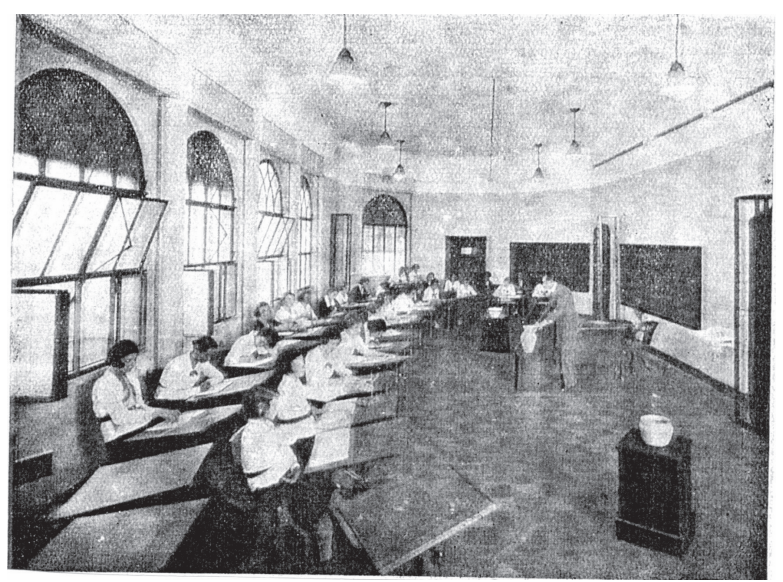

Fonte: Arquivos do Instituto de Educação, v. I, n. 1, jun. 1934. (encarte).

${ }^{7}$ Depoimento de Maria Antonietta Bittencourt à autora, em 31 de outubro de 2001. 
dões necessárias ao ingresso na Escola de Professores, para a qual os jovens tinham de prestar uma prova após concluírem o primeiro ano do ciclo complementar da Escola Secundária. ${ }^{8}$

Implementada em março de 1932, quando da criação do estabelecimento, a Escola Secundária do instituto desafiava a lei federal que conferia à União a competência de prover ensino secundário para a população. Acreditamos que essa seja uma das razões para justificar a centralidade dos laboratórios e salas especializadas destinadas a um ensino secundário que se assemelhasse ao padrão representado pelo Colégio Pedro II, mantido pelo governo federal. Além disso, a ênfase nas disciplinas científicas - biologia, física, química - em detrimento das demais revela o espírito que impregnava um curso secundário com vistas ao magistério, procurando incutir nos futuros mestres as bases científicas necessárias às disciplinas fundamentais da educação: biologia, psicologia e sociologia educacional. Durante o ano de 1933 foram também montados laboratórios para o ensino de psicologia educacional, gabinetes para o estudo de sociologia e estatística aplicada à educação, e um museu de higiene e puericultura. Todos os gabinetes encontravamse providos de farto material didático e audiovisual, aparelhos de projeção animada, inclusive para filmes sonoros. Instalou-se ainda no instituto a estação radiofônica PRD5, do Departamento de Educação, tendo em vista a irradiação de lições, concertos e conferências.

${ }^{8}$ Estamos referindo-nos à organização da Escola Secundária proposta pela Reforma Francisco Campos (decreto n. 19.890 de 18 de abril de 1931). Por essa reforma, a escola secundária dividia-se em dois ciclos: o fundamental, com cinco anos de duração, e o complementar, de dois anos. No caso dos alunos do Instituto de Educação que quisessem prosseguir na carreira do magistério ingressando na Escola de Professores bastava cursar o $1^{\circ}$ ano do ciclo complementar, também chamado de $6^{\mathrm{a}}$ série pelos alunos. Ver a respeito o parágrafo único do artigo $5^{\circ}$ do decreto $n$. 3.810 de 19 de março de 1932 (Prefeitura do Distrito Federal, 1932).
O critério de aprovação para o ingresso na Escola de Professores era rigoroso, visto que só se ofereciam 100 vagas, enquanto o número de alunos matriculados na Escola Secundária era bem superior. Entretanto, muitos destes desistiam da carreira do magistério, seja porque optassem por outras profissões, seja porque não desenvolvessem as aptidões necessárias.

Pelas informações colhidas no periódico, no artigo escrito pelo professor Lourenço Filho - "A Escola de Professores - notícia histórica" (1934) - sabese que no primeiro ano desse curso se estudava, prioritariamente, os Fundamentos da Educação, e no segundo, a aplicação. Compreendendo o último trimestre do $1^{\circ}$ ano e parte do $2^{\circ}$ ano, para unir a parte teórica à parte essencialmente prática do ensino, encontravam-se os estudos de caráter intermediário, pelos quais os princípios da teoria e os problemas da prática eram confrontados.

Como cada ano letivo se dividisse em três períodos, no $1^{\circ}$ ano cursava-se intensivamente, nos três períodos: a) biologia educacional, b) psicologia educacional; c) sociologia educacional. Paralelamente, por todo o curso, estendia-se o curso de história da educação, além dos cursos de artes, música e educação física. Era ministrada, ainda no $1^{\circ}$ ano, uma disciplina denominada Introdução ao Ensino, apresentando um panorama geral das questões a serem estudadas, nas quais se destacavam as funções da escola e as competências do professor.

$\mathrm{O} 2^{\circ}$ ano, de aplicação, tinha como ponto alto a Prática de Ensino, desenvolvida em três fases: observação, participação e direção de classe. Mais da metade da carga horária semanal era dedicada à prática, e todas as demais matérias a ela se articulavam. Os estudos intermediários, iniciados no ano anterior, tornam-se intensivos no $1^{\circ}$ trimestre do $2^{\circ}$ ano, e ao final os alunos eram levados aos debates das questões propostas pelo curso de fillosofia da educação.

Os chamados estudos intermediários compreendiam a seção Matérias de Ensino. Tratava-se, na prática, de uma adaptação dos conhecimentos vistos sob o ponto de vista do ensino, peculiar aos Teachers Colleges norte-americanos e que não se confundiam 
com didática ou metodologia. Estudava-se individualmente e com professores especializados: cálculo, leitura e linguagem, literatura infantil, ciências naturais e estudos sociais.

Essas matérias de ensino apareciam como a grande inovação implementada na matriz curricular dos estudos superiores do magistério primário. Traduziase como produto das reflexões de Anísio Teixeira à luz do pensamento de John Dewey, para quem o material básico de estudo não poderia ser colhido de maneira acidental e desordenada, e sim da experiência atual do aluno, na qual residem as fontes dos problemas a serem investigados (Dewey apud Cunha, 1999, p. 80).

Estudadas à luz da ciência, tais matérias articulavam o saber científico da seção de educação com a prática docente: não se tratava apenas de transmitir conhecimentos básicos, nem se resumiam a simples métodos, mas eram um processo global pelo qual o conteúdo e a metodologia se apresentavam inseparáveis, rompendo as fronteiras disciplinares, desenvolvidos na forma de projetos, a partir dos interesses do aluno.

No texto fotográfico, revelam-se imagens da Escola de Professores, em que alunos, sem uniforme, como convinha a um curso superior, se dedicam à pesquisa bibliográfica, em pequenos grupos, na aula de sociologia, um dos conteúdos disciplinares da área das ciências da educação.

Figura 5: Alunos da Escola de Professores em aula de Sociologia.

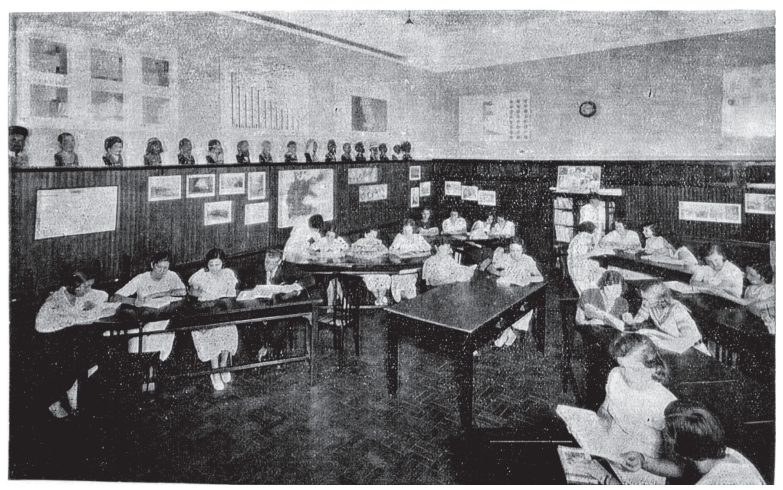

Fonte: Arquivos do Instituto de Educação, v. I, n. 1, jun. 1934. (encarte)
Representando a quarta subsérie, algumas fotografias, cuidadosamente selecionadas, captam imagens do prédio: a primeira, assinada pelo fotógrafo Malta, produtor oficial das imagens da Prefeitura do Distrito Federal, retrata a fachada do instituto, registrando a obra monumental de Fernando de Azevedo, construída na administração do prefeito Prado Júnior e transformada, durante a gestão de Anísio Teixeira, em Instituto de Educação.

De acordo com Moreira (1997), "um papel especial foi reservado à fotografia neste projeto de implantação da modernidade" (p. 74). Antes mesmo de ser considerada expressão artística, a fotografia era vista como expressão da ciência e, portanto, identificada com o signo do progresso. Nesse contexto podem ser entendidos os trabalhos realizados por Augusto Malta (1864-1957), um dos fotógrafos do início do século passado que melhor registrou as transformações urbanísticas verificadas nas principais cidades brasileiras, especialmente o Rio de Janeiro, então Distrito Federal. Convidado por Pereira Passos para ocupar o cargo de "fotógrafo documentalista" da prefeitura, registrou a execução e inauguração de obras públicas - escolas, hospitais, prédios históricos que seriam demolidos, festas organizadas pela prefeitura etc. Como afirma Moreira (1997, p. 76), sua função era "documentar a passagem, a transformação de uma cidade ainda tipicamente colonial em uma verdadeira metrópole e, através dela, 'civilizar' os hábitos e costumes da população".

O projeto fotográfico de Malta (Figura 6) enquadrava-se, portanto, no projeto maior do Estado, voltado para a modernização do Rio de Janeiro a fim de mostrar para o restante do país e para os países "civilizados" a imagem de um centro moderno e progressista. A fachada do Instituto de Educação, prédio típico do estilo neocolonial brasileiro, traduzia-se como ícone da modernidade pedagógica, iniciada na gestão Prado Júnior e aperfeiçoada com novas instalações e moderna aparelhagem de ensino na gestão Pedro Ernesto.

Outra fotografia (Figura 7) privilegiava a parte administrativa da escola, situada no segundo pavimento, com vista para o pátio, espaço para onde e de onde 
Figura 6: Aspecto externo do Instituto de Educação. Foto Augusto Malta.

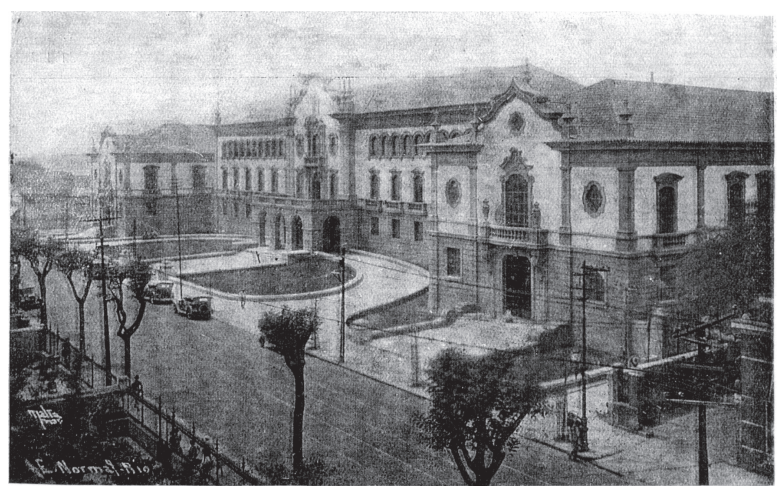

Fonte: Arquivos do Instituto de Educação, v. I, n. 1, jun. 1934. (encarte).

emerge toda a vida escolar, que poderia, assim, ser mais bem controlada. Esse pavimento abrigava o espaço de poder: a sala da direção, dos administradores, a sala dos inspetores responsáveis pela disciplina, a biblioteca - centro de referência da cultura renovada - e as instalações da Escola de Professores, que ocupava o primeiro lugar na hierarquia dos cursos da instituição, razão maior de sua existência. A racionalidade dos espaços, bem como a higiene dos corredores e pátios e o conforto das salas, pressupõem uma ordem a ser mantida, valores caros à época, incorporados aos princípios da escola renovada, que pregava a conciliação entre liberdade de expressão, pensamento e práticas, com normas de higiene e disciplina - uma liberdade com responsabilidade, dentro da ordem.

Figura 7: Vista do segundo pavimento do prédio

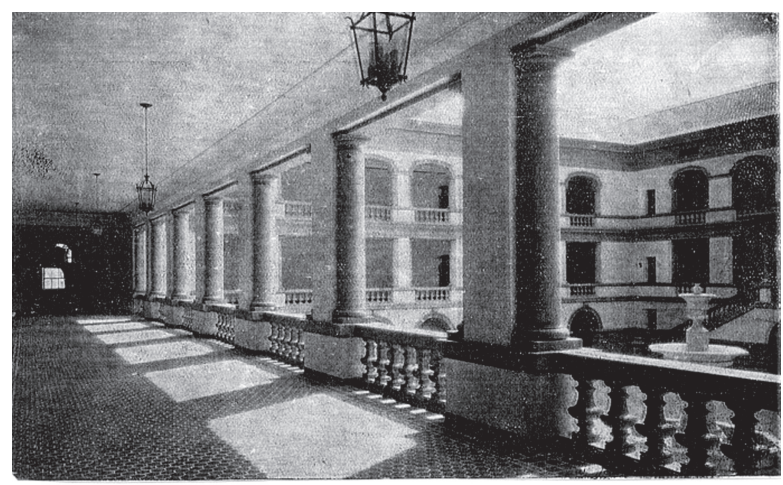

Fonte: Arquivos do Instituto de Educação, v. I, n. 1, jun. 1934. (encarte).

\section{Considerações finais}

Os Arquivos do Instituto de Educação dão-nos a impressão de conter experiências intransmissíveis, porque desapareceram com aqueles que a viveram. Seu simbolismo reside no fato de serem espaços destinados a registrar e perpetuar experiências encetadas pelos dirigentes da instituição, repletas de significações e representações de quem viveu a experiência do poder. Tudo o que ali se revela parece convincente, especialmente os documentos fotográficos, instantâneos impregnados de "verdades".

Entretanto, como nos adverte Mauad (1996), a idéia de que o que está impresso na fotografia é a realidade pura e simples já foi contestada por diferentes campos de conhecimento, e a crítica a essa dimensão mimética da imagem fotográfica envolve um exercício de interpretação dessa imagem, que é sempre datada e historicamente construída. É ainda a autora quem nos instiga: como superar essa limitação? Como enxergar o que não foi imediatamente revelado pela fotografia, ultrapassando a superfície da mensagem fotográfica e, "do mesmo modo que Alice nos espelhos, ver através das imagens?” (p. 80).

É esse certamente o desafio da história: apropriarse da matéria-prima contida nos textos da memória construída e perceber, por trás deles, aquilo que não foi selecionado, o que não foi ou não pôde ser dito. É justamente pelo cruzamento das diversas fontes, por uma operação metódica e crítica, que o historiador procura interpretar os fatos, sem perder a clareza de que, assim como a memória pode ser deliberadamente construída, sua versão sobre os fatos também não escapa ao processo de construção.

Assim, encaminhando os alunos pela observação de suas aptidões, valendo-se de instrumentos de controle e padronização, como os testes aplicados às crianças que ingressavam na Escola Secundária, o instituto levava a termo sua experiência de alto $\mathrm{cu}$ nho social, selecionando e preparando os mais capazes para a função de educar. À luz dos paradigmas que transformavam o pensamento educacional da época, pretendeu-se fixar na memória coletiva as ima- 
gens do Instituto de Educação do Rio de Janeiro como centro irradiador de uma nova ordem, uma nova cultura pedagógica que se expandiria para o restante do país. Os agentes construtores dessa memória, tendo à frente Lourenço Filho, orgulhavam-se da obra que estrategicamente iam moldando - a obra-síntese da reconstrução educacional, que, sob seus olhos, adquiria formas, contornos mais nítidos, saía do decreto, simples papel, para ganhar vida.

\section{Referências bibliográficas}

ALMEIDA, Jane Soares de. Mulher e educação: a paixão pelo possível. São Paulo: UNESP, 1998.

ARQUIVOS DO INSTITUTO DE EDUCAÇÃO. Rio de Janeiro, Distrito Federal: Officinas Graphicas do Departamento de Educação, v. I, n. 1, jun. 1934.

AZEVEDO, Fernando de. A reforma de ensino no Distrito Federal: discursos e entrevistas. São Paulo: Melhoramentos, 1929.

. Novos caminhos e novos fins: a nova política de educação no Brasil. São Paulo: Cia. Editora Nacional, 1931.

BARTHES, Roland. A câmara clara: nota sobre a fotografia. Rio de Janeiro: Nova Fronteira, 1984.

BRASIL. Decreto-lei n. 1.063, de 20 de janeiro de 1939. Dispõe sobre a transferência de estabelecimentos de ensino da Universidade do Distrito Federal para a Universidade do Brasil. Diário Oficial, seção II, s.p., 2 fev. 1939. [Acervo de Obras Raras do Instituto Superior de Educação do Rio de Janeiro.]

BRITO, Mário de. Lourenço Filho e o Instituto de Educação. In: ASSOCIAÇÂO BRASILEIRA DE EDUCAÇÃO. Lourenço Filho um educador brasileiro. São Paulo: Melhoramentos, 1959. p. $69-72$.

CHARTIER, Roger. A história cultural: entre práticas e representações. São Paulo: Difel, 1990.

CHAUÍ, Marilena. Cultura e democracia: o discurso competente e outras falas. São Paulo: Moderna, 1982.

CUNHA, Marcus Vinicius da. John Dewey: uma filosofia para educadores em sala de aula. 3. ed. Petrópolis: Vozes, 1999.

HALBWACHS, Maurice. A memória coletiva. São Paulo: Vértice/Revista dos Tribunais, 1990.

KOSSOY, Boris. Fotografia \& história. São Paulo: Ateliê Editorial, 2001.
LOURENÇO FILHO, M. B. A Escola de Professores do Instituto de Educação - notícia histórica. Arquivos do Instituto de Educação, v. I, n. 1, p. 15-26, jun. 1934.

MAUAD, Ana Maria. Através da imagem: fotografia e história interfaces. Tempo, Niterói, v. 1, n. 2, p. 73-98, 1996.

MOREIRA, Regina da Luz. Trópico versus civilização nas imagens de Augusto Malta. Cadernos de Antropologia e Imagem, Rio de Janeiro, v. 4, n. 1, p. 71-89, 1997.

NORA, Pierre. Entre memória e história: a problemática dos lugares. Trad. Yara Khoury. Projeto História, São Paulo: PUC-SP, n. 10, p. 7-28, dez. 1993.

NUNES, Clarice. (Des)encantos da modernidade pedagógica. In: LOPES, Eliane; FARIA FILHO, Luciano; VEIGA, Cynthia (Orgs.). 500 anos de educação no Brasil. Belo Horizonte: Autêntica, 2000. p. 371-398.

PANOFSKY, Erwin. Significado nas artes visuais. 2. ed. São Paulo: Perspectiva, 1979.

PREFEITURA DO DISTRITO FEDERAL. Decreto n. 3.810, de 19 de março de 1932. Organização do Instituto de Educação do Rio de Janeiro. Regula a formação technica de professores primários, secundários e especializados para o Districto Federal, com a prévia exigência do curso secundário e transforma em Instituto de Educação a antiga Escola Normal e estabelecimentos anexos. Rio de Janeiro: Officinas Graphicas do Jornal do Brasil, 1932. [Acervo de Obras Raras do Instituto Superior de Educação do Rio de Janeiro.]

SAMPAIO, Nereo. O ensino de desenho. Arquivos do Instituto de Educação, v. I, n. 1, p. 35-48, jun. 1934.

VENÂNCIO FILHO, Francisco. Instituto de Educação do Distrito Federal. Arquivos do Instituto de Educação, v. II, n. 1, p. 19-32, dez. 1945.

VIDAL, Diana; PAULILO, André Luiz. Projetos de estratégia e implementação da Escola Nova na capital do Brasil (1922-35) In: MAGALDI, Ana Maria; ALVES, Cláudia; GONDRA, José (Orgs.). Educação no Brasil: história, cultura e política. Bragança Paulista: EDUSF, 2003. p. 375-398.

SONIA DE CASTRO LOPES, historiadora, doutora em educação pela Pontifícia Universidade Católica do Rio de Janeiro (PUC-Rio), é professora adjunta de educação brasileira da Faculdade de Educação da Universidade Federal do Rio de Janeiro (UFRJ). Últimas publicações: Oficina de mestres: história, me- 
mória e silêncio sobre a Escola de Professores do Instituto de Educação do Rio de Janeiro (1932-39) (Rio de Janeiro: DP\&A/ FAPERJ, 2006); “Arquivos do Instituto de Educação: suporte de memória da educação nova no Distrito Federal" (Revista Brasileira de História da Educação, n. 9, p. 43-72, jan./jun. 2005). Suas pesquisas concentram-se sobre a história da formação docente na cidade do Rio de Janeiro, adotando como campo empírico o atual Instituto Superior de Educação do Rio de Janeiro (ISERJ), tradicional centro de formação de professores. Coordena nessa insti- tuição o Projeto Memória (PROMEMO/ISERJ), além de integrar o grupo de pesquisadores do Programa de Estudos e Documentação Educação e Sociedade (PROEDES) na Faculdade de Educação da UFRJ, no qual investiga a formação de professores secundários na antiga Universidade do Distrito Federal (UDF). E-mail: sm.lopes@globo.com

Recebido em março de 2007 Aprovado em setembro de 2007 
Sonia de Castro Lopes

Imagens de um lugar de memória da Educação Nova: Instituto de Educação do Rio de Janeiro nos anos de 1930

$\mathrm{O}$ artigo utiliza imagens fotográficas para sublinhar a importância conferida ao Instituto de Educação do Rio de Janeiro como um dos mais expressivos laboratórios da Escola Nova. Trata-se, na verdade, de um lugar de memória (Nora, 1993) privilegiado desse movimento, servindo de referencial para o país durante a década de 1930 como centro de excelência na formação de professores. As imagens analisadas foram veiculadas pelo periódico Arquivos do Instituto de Educação, publicado pela primeira vez em 1934, sob os aus- pícios da Secretaria de Educação do Distrito Federal. Busca-se aqui superar a idéia da fotografia como mera ilustração para as análises escritas, considerando-a fonte histórica que requer uma construção teórico-metodológica singular.

Palavras-chave: fotografia; memória; formação de professores; Instituto de Educação

Images from a legacy site of the new education: the Rio de Janeiro Institute of Education in the 30's

This article uses photographic images to highlight the key role played by the Rio de Janeiro Institute of Education as one of the most significant experiential spaces of the New Education. It deals with a privileged legacy site (Nora, 1993) of this reform movement which, as a centre of excellence in teacher education, served as a point of reference for the whole country throughout the 1930s. The images that were analysed were published by the periodical Arquivos do Instituto de Educação (Archives of the Institute of Education) which was launched in 1934 under the auspices of the Secretariat of Education of the Federal District. This article seeks to surpass the concept of photography as mere illustration for written texts and to regard photography as a historical source that requires a specific theoretical and methodological construction.

Key words: photography; legacy; teacher education; Institute of Education

Imágenes de un sitio de memoria de la nueva educación: Instituto de Educación de Rio de Janeiro en los años de 1930

El artículo utiliza imágenes fotográficas para subrayar la importancia concedida al Instituto de Educación de Rio de Janeiro como uno de los más expresivos laboratorios de 
la Nueva Escuela. En realidad se trata de un privilegiado sitio de memoria (Nora, 1993) de ese movimiento, que sirvió de referencia para el país en los años 1930 como centro de excelencia en la formación de profesores. Las imágenes analizadas fueron difundidas por el periódico Arquivos do Instituto de Educação (Archivos del Instituto de Educación), publicado por primera vez en 1934 bajo los auspicios de la Secretaría de Educación del Distrito Federal. Se busca aqui modificar la idea que considera a la fotografia como simple ilustración de análisis escrita y considerarla como fuente histórica que requiere una construcción teórico-metodológica particular.

Palabras claves: fotografia; memoria; formación de profesores; Instituto de Educación 